\title{
Heterogeneity in bacterioplankton abundance from 4.5 millimetre resolution sampling
}

\author{
Justin R. Seymour, James G. Mitchell ${ }^{*}$, Lyn Pearson, Raechel L. Waters \\ Biological Sciences, Flinders University, PO Box 2100, Adelaide, South Australia 5001, Australia
}

\begin{abstract}
A suite of pneumatically operated sampling devices was employed to investigate distributional patterns of marine bacteria at the millimetre scale. Spatial heterogeneity in bacterial abundance, or patchiness, was expressed as a coefficient of variation, and ranged from 5.5 to $75 \%$. Discrete regions of enhanced bacterial abundance, as well as clear gradients in abundance across entire sample arrays were observed, with changes in bacterial abundance of up to 16 -fold observed across a distance of $32 \mathrm{~mm}$. The role of turbulence in influencing bacterial distribution patterns was examined in a series of laboratory experiments. Levels of heterogeneity were found to be up to 6.5 times higher in stirred than unstirred water samples under laboratory conditions. The gradients in bacterial abundance observed here suggest that small-scale processes operate within the marine microenvironment to create and maintain spatial structure in the bacterioplankton community. We suggest that previously hypothesised nanoscale 'hot spots' and microzones exist only as maxima within a continuously variable distribution of bacteria within the marine environment.
\end{abstract}

KEY WORDS: Marine bacteria $\cdot$ Spatial heterogeneity $\cdot$ Patchiness $\cdot$ Turbulence $\cdot$ Small-scale

Resale or republication not permitted without written consent of the publisher

\section{INTRODUCTION}

Bacteria represent a major pathway in the flux of organic matter through marine systems, and consequently play a vital role in nutrient cycling and foodweb structure within the marine environment (Pomeroy 1974, Azam et al. 1983). Furthermore, the role of heterotrophic bacteria may extend to have significant implications for ocean-scale biogeochemical cycles (Azam 1998, Cho \& Azam 1988). However, our understanding of the factors controlling the ecology and structure of the marine bacterial community remains limited.

To gain an adequate understanding of the ecology of marine bacteria at scales of ecological significance, knowledge of small-scale bacterioplankton spatial dynamics is vital. It has been hypothesised that marine bacteria aggregate into small-scale patches or 'hot spots' in response to favourable environmental conditions, such as around the dissolved organic matter diffusing from phytoplankton cells (Mitchell et al. 1985, Bowen

*Corresponding author. E-mail: jim.mitchell@flinders.edu.au et al. 1993), organic particles (Shanks \& Trent 1979, Alldredge \& Cohen 1987), and discrete microscale nutrient patches (Lehman \& Scavia 1982, Blackburn et al. 1997, 1998).

Direct evidence for such nanoscale (10 to $100 \mu \mathrm{m})$ bacterial heterogeneity within the marine environment has, however, rarely been obtained. Müller-Niklas et al. (1996) were unable to find evidence for bacterial aggregations in relation to phytoplankton cells, and Krembs et al. (1998a,b) were only able to observe bacterial patches in manipulated lake water samples using the Spatial Information Preservation (SIP) method.

Spatial heterogeneity in bacterial abundance has, however, been readily observed in natural samples at the centimetre scale (Mitchell \& Fuhrman 1989, Duarte \& Vaqué 1992), with changes in abundance of up to 3.5 -fold observed across distances of $10 \mathrm{~cm}$ in natural seawater samples (Mitchell \& Fuhrman 1989). Clearly, a gap in the published research investigating smallscale bacterial distributions exists between micrometre and centimetre scales. The next logical step is to sample between these scales. The millimetre sampling scale allows for accurate high resolution field sampling in a range of aquatic habitats, but prohibits the identifica- 
tion of nanoscale events including the aggregation of bacteria around phytoplankton cells and nutrient patches. In recent times, however, it has become apparent that, as well as these nanoscale events, there are potentially many other small-scale processes occurring within the ocean which may create ecologically significant levels of bacterial spatial heterogeneity.

Previously it was inferred that small-scale heterogeneity in bacterial abundance would consist of discrete nanoscale hot spots of enhanced bacterial abundance occurring periodically against a background of homogeneity. A more recent view of the ocean paints an increasingly complicated picture, consisting of a dynamic organic matter continuum, composed of a gellike matrix containing embedded polymers, particles, and organisms (Azam 1998). The heterogenous structure of this microenvironment is likely to create discrete microniches, supporting increased levels of bacterial abundance and diversity (Azam 1998), and in turn lead to small-scale variability in bacterial abundance.

In addition to the structure and complexity presented by the organic matter continuum are the dynamics generated by the influence of small-scale turbulence. Small-scale turbulence plays an important role in the distribution patterns and ecology of zooplankton and phytoplankton (Haury et al. 1990, Kiørboe 1993, Yamazaki 1993, Powell \& Okubo 1994). Variations in turbulence levels have been shown to modify bacterioplankton community structure and production rates in laboratory experiments (Moeseneder \& Herndl 1995), but to our knowledge the influence of turbulence on small-scale bacterial distribution patterns in the sea has not been investigated. A number of potential effects associated with small-scale turbulence, including increased collision and coagulation of marine particles (McCave 1984, Kiørboe 1997, Ruiz 1997), preferential concentration of cells in regions of turbulent flow (Wang \& Maxey 1993, Squires \& Yamazaki 1995), and polymer dynamics (Harris \& Mitchell 1973, Calleja 1984, LeDuc et al. 1999), may be important for the generation of patchy distributions of marine bacteria. According to Mackas et al. (1985) all types and scales of planktonic patchiness are strongly influenced by hydrodynamic processes. It follows that, to increase our understanding of the processes influencing smallscale bacterioplankton dynamics, investigations into the influence of physical factors in marine microbial ecology are required.

Interactions between organisms, particles and the physical microenvironment create and maintain heterogenous distributions of planktonic communities at several length scales. Here we measure variations in bacterial abundance at the millimetre scale within the marine environment, and present evidence for het- erogenous distributions of bacteria at this scale. Evidence for the existence of clear structure in bacterial distribution patterns is presented, as is evidence for the potential importance of physical mixing in the creation and maintenance of these structures.

\section{MATERIALS AND METHODS}

Sampling equipment. Three pneumatically operated sampling devices were employed to measure distributions of marine bacteria in the field. The first of these systems consisted of two 8-place autopipettes (Brand Transferpette-8) combined to form a linear array of 16 tips, each separated by a distance of $4.5 \mathrm{~mm}$, and capable of simultaneously taking a $50 \mu \mathrm{l}$ sample. This linear sampling device is a scaled-down version of sampling devices previously used to monitor bacterial distributions at larger scales (Mitchell \& Fuhrman 1989), and was employed to allow easy comparison between the distributions found here, and those observed at larger scales by other workers.

To obtain a more detailed insight into bacterial distribution patterns, a sampling device capable of monitoring bacterial distributions in 2 dimensions was constructed, consisting of an array of $5 \times 5,1 \mathrm{ml}$ syringes, each separated by $8 \mathrm{~mm}$ and modified to sample volumes of only $50 \mu \mathrm{l}$. The syringes were held in perspex casing, incorporating an air space with an approximate volume of $30 \mathrm{~cm}^{3}$, which could be evacuated when attached to a small electric pump. The vacuum pulled back the plunger of each syringe within less than a second, allowing 25 samples to be collected across a total area of approximately $16 \mathrm{~cm}^{2}$. A $9 \times 9$ version of this device was employed to increase sample number and area (Fig. 1). Samples were taken from 5 to $15 \mathrm{~cm}$ below the water surface.

While sampling in very turbulent conditions, where waves and surges were present, the sampling action was timed to coincide with lulls between waves or surges to ensure the position of the sampling device in the water column.

Field sampling procedures. Water samples were collected and analysed from 5 near-shore study sites including estuarine habitats, wave-exposed beaches, and a coastal jetty. Study sites were selected to provide a range of environmental conditions, including variations in levels of turbulence and concentrations of bacteria.

(1) The Southport Beach, South Australia (35 $10^{\prime} \mathrm{S}$, $\left.138^{\circ} 28^{\prime} \mathrm{W}\right)$, study site was selected to examine bacterial distribution patterns within a highly turbulent environment, in this case a wave-exposed beach. Samples were collected from 5 to $15 \mathrm{~cm}$ below the water surface, in water of $1.5 \mathrm{~m}$ depth, where waves of 30 to $60 \mathrm{~cm}$ were breaking. 
(2) The Onkaparinga River estuary, South Australia $\left(35^{\circ} 10^{\prime} \mathrm{S}, 138^{\circ} 29^{\prime} \mathrm{W}\right)$, study site was situated approximately $100 \mathrm{~m}$ up-stream from the sample site at Southport Beach, and was selected to represent a non-turbulent example from within the same region as Southport Beach. Water movement at this site is generally low $\left(<3 \mathrm{~m} \mathrm{~min}^{-1}\right)$ and at the time of sampling was negligible.

(3) Sampling from a platform at the end of the Port Noarlunga jetty (pier) $\left(35^{\circ} 09^{\prime} \mathrm{S}, 138^{\circ} 28^{\prime} \mathrm{W}\right)$, located $1 \mathrm{~km}$ north of the Southport Beach site, allowed us to obtain samples from a highly turbulent environment, but at greater water depth $(6 \mathrm{~m})$ than at the Southport Beach site.

(4) The St Kilda Mangroves ( $34^{\circ} 44^{\prime} \mathrm{S}, 138^{\circ} 32^{\prime} \mathrm{W}$ ) study site was selected to represent an environment of high bacterial concentrations $\left(10^{7} \mathrm{ml}^{-1}\right)$, and was situated within a mangrove system, and characterised by a wide $(10$ to $15 \mathrm{~m})$ flowing $\left(5 \mathrm{~m} \mathrm{~min}^{-1}\right)$, tidally driven, saltwater (>35 ppt year round) stream of approximately $0.5 \mathrm{~m}$ depth.

(5) The Port River Estuary study site $\left(34^{\circ} 51^{\prime} \mathrm{S}\right.$, $138^{\circ} 30^{\prime} \mathrm{W}$ ) was situated within a sheltered saltwater (35 ppt) complex exposed to high levels of urban and industrial waste and intermittent flow of fresh water, and like the St Kilda site is characterised by high bacterial concentrations. Water movement at the Port River study site occurs at moderate to low levels $\left(<0.1 \mathrm{~m} \mathrm{~s}^{-1}\right)$. Samples were collected from a floating pontoon platform in water of approximately $5 \mathrm{~m}$ depth.

At each of the study sites the 1-dimensional and the $5 \times 5$ and $9 \times 9$ 2-dimensional sampling arrays were employed to take samples from $0.5 \mathrm{~m}$ from the edge of the platforms.

Sample preparation and analysis. Acridine orange direct counts (AODC): Fifty microlitre sub-samples were fixed immediately with $0.2 \mu \mathrm{m}$ filtered formaldehyde solution (2.5\% final conc.). Samples were stained with $5 \mu \mathrm{l}$ of $0.2 \mu \mathrm{m}$ filtered Acridine Orange solution $(0.1 \%)$, and cells enumerated with fluorescence microscopy (Hobbie et al. 1977), using a Leitz dialux 20 EB epifluorescence microscope attached to a Leitz $12 \mathrm{~V}$ Quartz lamp, at $1000 \times$ magnification. Prior to microscopy, a modified filtration technique was used due to the small sample volumes. Each $50 \mu$ stained sample was pipetted directly onto a filter (Millipore GTBP $0.2 \mu \mathrm{m}$, $25 \mathrm{~mm}$ diameter) and the diameter of the stained area was measured after filtration with microcalipers. To prevent running when the sample occasionally did not form a contained droplet, a cut down $10 \mathrm{~mm}$ diameter, $3 \mathrm{ml}$ Terumo brand syringe was used as a filter guide. This technique led to even distributions of bacteria across an area of about $55 \mathrm{~mm}^{2}$, and allowed for
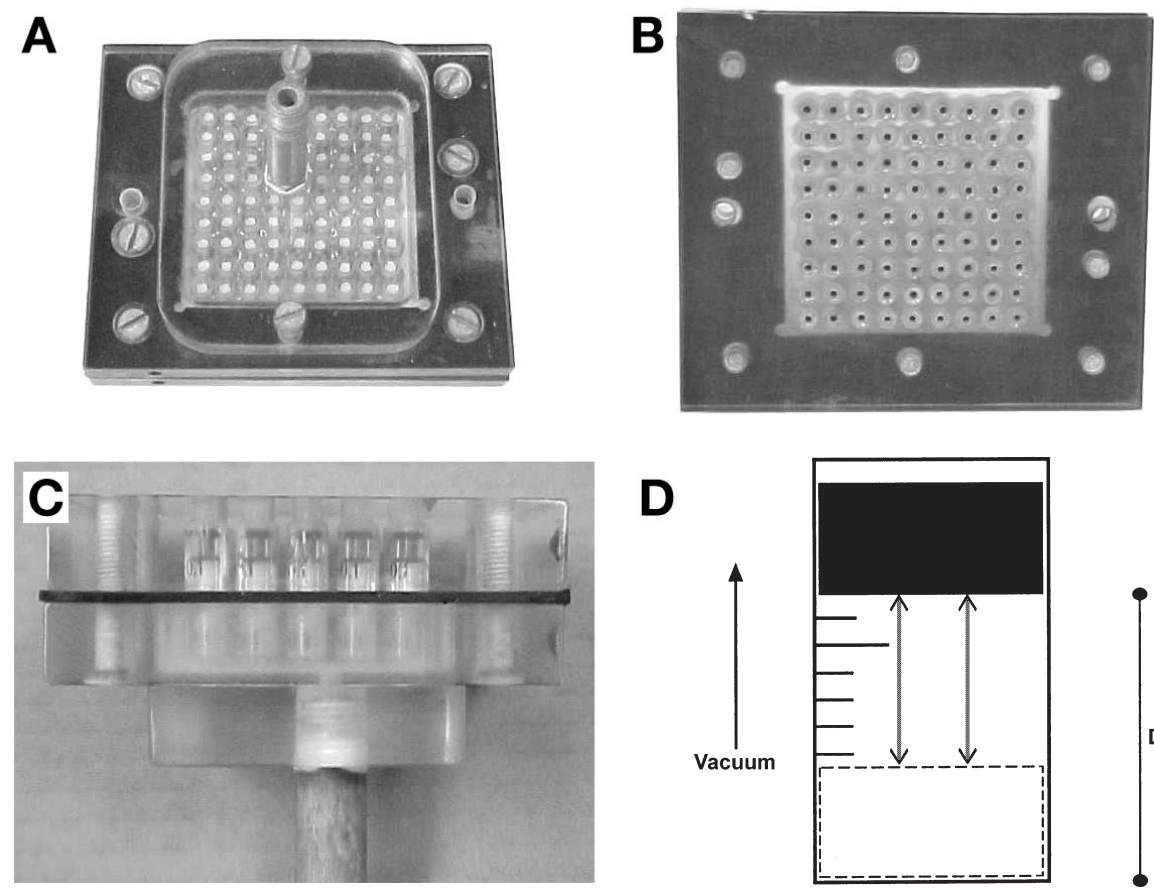

Fig. 1. Construction of the 2-dimensional sampling devices. (A) Above view clearly showing the internal structure of the $9 \times 9$ device with 81 sample syringe chambers and the central tubing which was attached to a vacuum pump. (B) Underneath view of the $9 \times 9$ sampler showing the 81 sample syringes each separated by a distance of $8 \mathrm{~mm}$. (C) Side view along one edge of the $5 \times 5$ sampler, where the sample syringes embedded in perspex casing can be seen. (D) Schematic diagram of 1 sample syringe from within the 2-dimensional samplers. Dashed and black boxes represent the syringe plunger before and after the sample has been collected. $\mathrm{D}=$ distance moved by syringe plunger following vacuum suction 
greater numbers of bacteria to be counted per field of view. Two hundred to 2000 bacteria were counted from 10 to 20 microscope fields of view for each sample.

Flow cytometric analysis: For a more rapid analysis of multiple samples, flow cytometry was used to enumerate bacteria concentrations in sub-samples collected with the $9 \times 9$ 2-dimensional sampling array. To allow an adequate amount of sample to be run through the flow cytometer, $50 \mu$ samples were diluted with $450 \mu \mathrm{l}$ of filtered $(0.2 \mu \mathrm{m}$, filtered $\times 3)$ seawater. Samples were fixed with $10 \mu \mathrm{l}$ of $10 \%$ paraformaldehyde and quick-frozen in liquid nitrogen in the field, before being stored at $-80^{\circ} \mathrm{C}$ upon return to the laboratory.

Prior to flow cytometric analysis, samples were quickthawed, and incubated for $30 \mathrm{~min}$ following the addition of a $0.1 \mathrm{~g}$ mixture of ribonuclease (RNase) A and B (1:1 wt/wt r4875 and R 5750, Sigma Chemical) (Marie et al. 1997). Following incubation, each sample was stained with SYBR-I Green solution (Molecular Probes) and incubated for $15 \mathrm{~min}$ in the dark (Marie et al. 1997). Samples were analysed using a Becton-Dickinson FACScan flow cytometer, with PBS (phosphate buffered saline) employed as a sheath fluid. Fluorescent beads of $1 \mu \mathrm{m}$ diameter (Molecular Probes) were added to samples and all measured parameters were normalised to bead concentration and fluorescence. For each sample, forward-angle light scatter (FALS), right-angle light scatter (RALS), green (SYBR-I) fluorescence, red (chlorophyll) fluorescence, and orange (phycoerythrin) fluorescence were acquired. Acquisition was run until $50 \mu \mathrm{l}$ of sample was analysed at a rate of approximately $50 \mu \mathrm{min}^{-1}$. Data were analysed and planktonic populations were identified and enumerated using the CYTOWIN program (Vaulot 1989).

For both AODC and flow cytometry techniques, bacterial concentrations were calculated per sample, and levels of heterogeneity across entire sample sets were calculated and expressed as coefficients of variation, allowing us to compare levels of heterogeneity between sample sets quantitatively.

Laboratory studies: bucket turbulence experiments. Five litres of seawater were collected in a clean 9.81 polypropylene bucket (radius $14 \mathrm{~cm}$ ) from the Port Noarlunga site. The bucket was transported to Flinders University, and allowed to settle for $24 \mathrm{~h}$ in a controlled temperature room where turbulence within the bucket due to convection could be minimised. A set of stillwater samples was then taken from $5 \mathrm{~cm}$ below the water surface in the centre of the bucket. The samples were fixed, stained, and analysed using the AODC techniques described above.

The bucket was then mixed to allow us to take water samples from the same body of water under turbulent conditions. To minimise disruption of flow related patterns, no internal devices were used for stirring. In- stead, the bucket was attached to a $1.25 \mathrm{~m}$ high tripod stand by a nylon rope, which was twisted 6 times, and then allowed to unravel.

For comparison with turbulence levels in the natural environment and those produced in other laboratory experiments, the energy dissipation rate of the stirred bucket was calculated. Measurement of the velocity of a drop of neutrally buoyant dye added to the sample allowed us to calculate the rotational velocity of the water sample at various time intervals (5 and $15 \mathrm{~s}$ after stirring). The rotational kinetic energy of the water in the bucket was then calculated for each time interval. The change in kinetic energy over time divided by the mass of the body of water provided us with a value for energy dissipation of the spinning bucket of water.

Five seconds after the rope unravelled, and the rotation of the bucket was stopped, a sample was taken from the centre of the bucket at $5 \mathrm{~cm}$ below the water surface, and analysed as above. Levels of heterogeneity in bacterial abundance across each sample set were calculated by determining the coefficient of variation, and compared using a $t$-test. This experiment was conducted using both the 1 -dimensional and $5 \times 5$, 2-dimensional sampling devices.

Distributions of different particles types in turbulence. To determine the extent to which particle shape influenced distribution patterns within turbulent flow, the distribution patterns of an unidentified species of rodshaped bacteria was compared to that of $1 \mu \mathrm{m}$ diameter spherical fluorescent beads (Molecular Probes). Final concentrations of both particle types were calculated to be comparable to those of bacteria observed in the field sampling studies $\left(10^{6} \mathrm{ml}^{-1}\right)$, and added to a $10 \mathrm{ml}$ solution of filtered seawater. Five millilitres of this solution was added to the centre of 51 of $0.2 \mu \mathrm{m}$ filtered sterile seawater in a 9.81 bucket. To mix particles into the solution the bucket was stirred as described above, 3 times before being allowed to settle for $30 \mathrm{~min}$. The bucket was then stirred once and the $5 \times 5$, 2-dimensional sampler was used to take a water sample from the centre of the bucket. Samples were prepared and analysed using the AODC techniques described above, and the distribution patterns of the rod-shaped bacteria and fluorescent spheres were compared.

\section{RESULTS}

\section{One-dimensional distributions}

The 1-dimensional sampling device was used to take water samples from the Southport Beach, Onkaparinga River and St Kilda Mangroves study sites. Mean bacterial abundances across sample sets ranged 
from $6.5 \times 10^{2}$ cells $\mu^{-1}$ at Southport Beach, to $1.0 \times 10^{4}$ cells ${\mu l^{-1}}^{-1}$ within the St Kilda mangroves.

Of the sample sites, the lowest level of variation in bacterial abundance occurred at the Onkaparinga River site, where a mean coefficient of variation (CV) of $13 \%$ across the sample distance of $63 \mathrm{~mm}$ was observed (Fig. 2A).
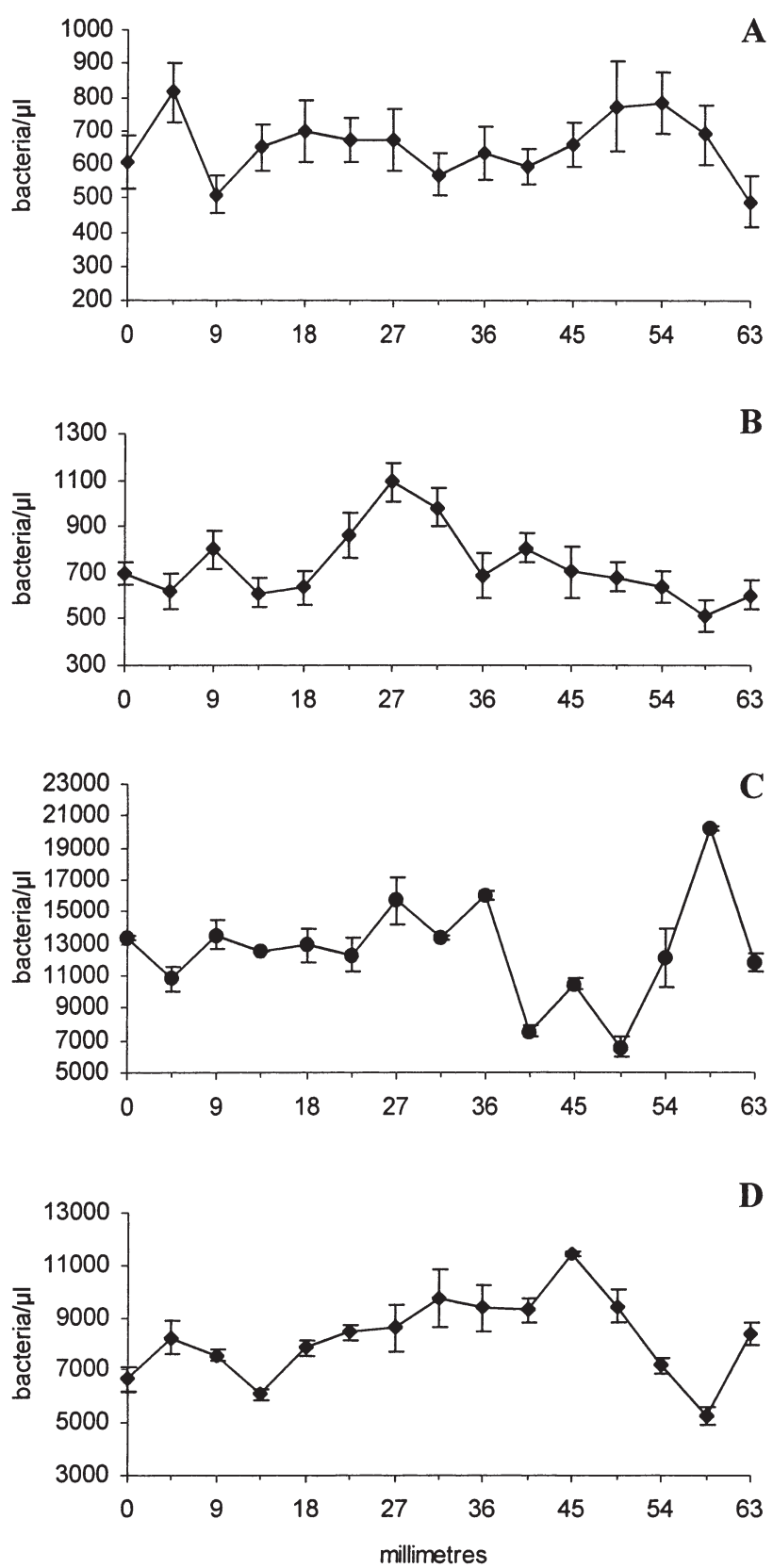

Fig. 2. Linear bacterial distributions from 3 near-shore study sites. (A) Onkaparinga River estuary. (B) Southport Beach surf zone. $(\mathrm{C}, \mathrm{D})$ St Kilda Mangroves site. Bacterial abundances at each point were obtained from individual $50 \mu \mathrm{l}$ sub-samples. Error bars represent $95 \%$ confidence levels associated with Acridine Orange direct count (AODC) techniques
At Southport Beach the mean CV for the sample sets was $19.5 \%$. Fig. 2B shows a clear peak in bacterial abundance and a 2.2 -fold total change in bacterial abundance across the sample distance of $63 \mathrm{~mm}$.

The mean CV for samples taken from the St Kilda Mangroves site was $24 \%$ (Fig. 2C,D). Fig. 2C shows both the highest concentration of bacteria $\left(10^{4} \mathrm{cells}_{\mathrm{H}} \mathrm{l}^{-1}\right)$, and the greatest CV $(26 \%)$ of all linear sample sets. A single peak in abundance is clearly evident, and a 3 -fold change in abundance across the length of the entire sample set was observed.

Statistically significant $(p<0.001)$ variation in levels of millimetre-scale bacterial heterogeneity was found to exist between sample sites, using the Kruskal-Wallis non-parametric test.

\section{2-dimensional distribution sampling}

The 2-dimensional sampling devices were used to take water samples from the Port Noarlunga and Port River study sites. Mean bacterial abundances for samples taken at Port Noarlunga were $9.7 \times 10^{2}$ bacteria $\mu^{-1}$, and levels of heterogeneity measured as CVs ranged from 20 to $38 \%$, with up to a 4.7 -fold change in total abundance occurring across sample areas (Fig. 3). Discrete regions of high and low bacterial abundance were observed, with both single point maxima, and large areas of both elevated and reduced bacterial abundance apparent.

The $9 \times 9$ sampler was used to obtain bacterial distribution patterns from the Port River site (Fig. 4), where mean bacterial concentrations were $4.5 \times 10^{3}$ bacteria $\mu^{-1}$. An apparent structure in bacterial abundance was also observed, with a large ( $2.5 \mathrm{~cm}$ wide) maximum region $\left(1.2 \times 10^{4}\right.$ bacteria $\left.\mu^{-1}\right)$, where bacterial concentrations are up to 2.75 times greater than mean levels. Also evident is a large region of low bacterial abundance $\left(6.8 \times 10^{2}\right.$ to $1.8 \times 10^{3}$ bacteria $\mu \mathrm{l}^{-1}$ ), 1 to $2 \mathrm{~cm}$ wide and stretching the length of the sample. A CV of $43 \%$ was calculated for this sample set.

\section{Laboratory studies: bucket turbulence experiments}

The mean CV observed for individual sample-sets taken initially from an unstirred bucket was $4.5 \%$. When the bucket of seawater was then stirred, the rotational velocity of a neutrally buoyant dye plume was found to be $1.6 \mathrm{rad} \mathrm{s}^{-1}$, equivalent to a linear velocity of $0.22 \mathrm{~m} \mathrm{~s}^{-1}, 5 \mathrm{~s}$ after mixing, and $0.7 \mathrm{rad} \mathrm{s}^{-1}$, equivalent to a linear velocity of $0.09 \mathrm{~m} \mathrm{~s}^{-1}, 15 \mathrm{~s}$ after the rope unravelled. The turbulent energy dissipation of the mixed water was calculated to be $0.25 \mathrm{~mW} \mathrm{~kg}^{-1}$. Mann \& Lazier (1991) categorise energy dissipation 


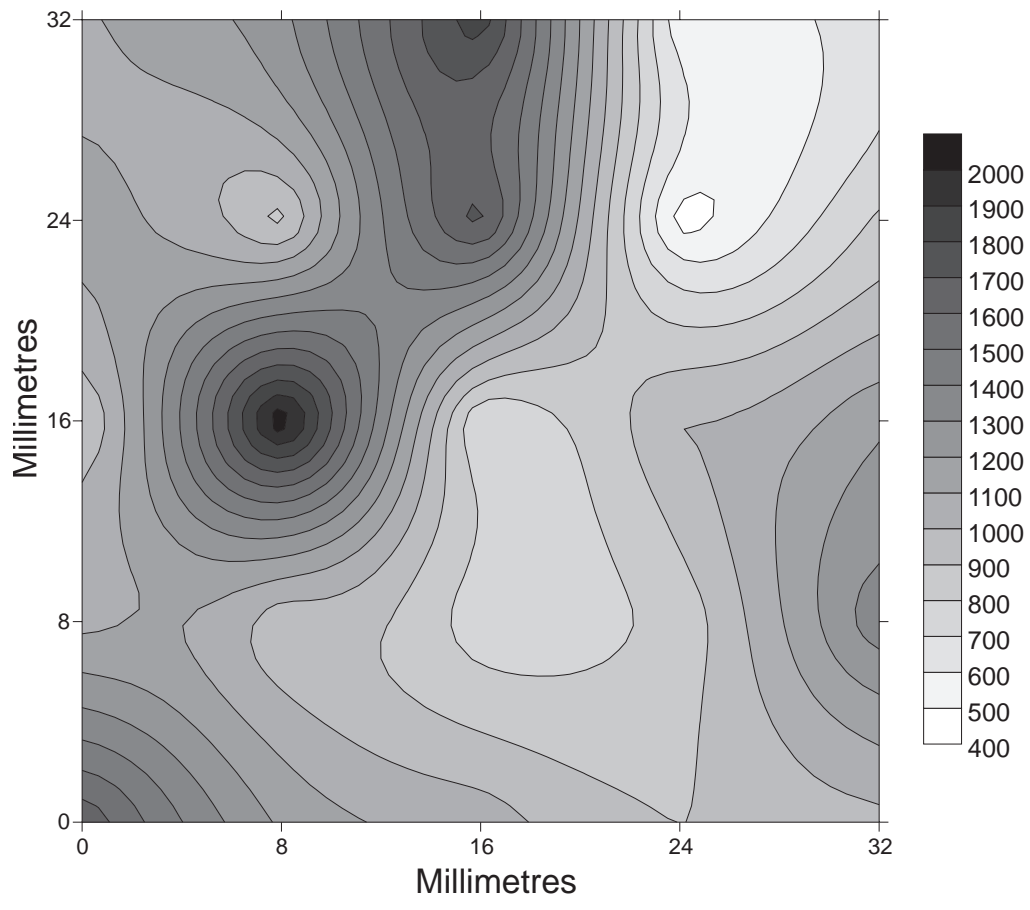

Fig. 3. Two-dimensional $(5 \times 5)$ bacterial distribution pattern observed at the Port Noarlunga study site. Contour graph represents an area of approximately $1000 \mathrm{~mm}^{2}$. Contour levels set at 100 bacteria $\mu^{-1}$, approximately equivalent to $95 \%$ confidence limits associated with AODC techniques

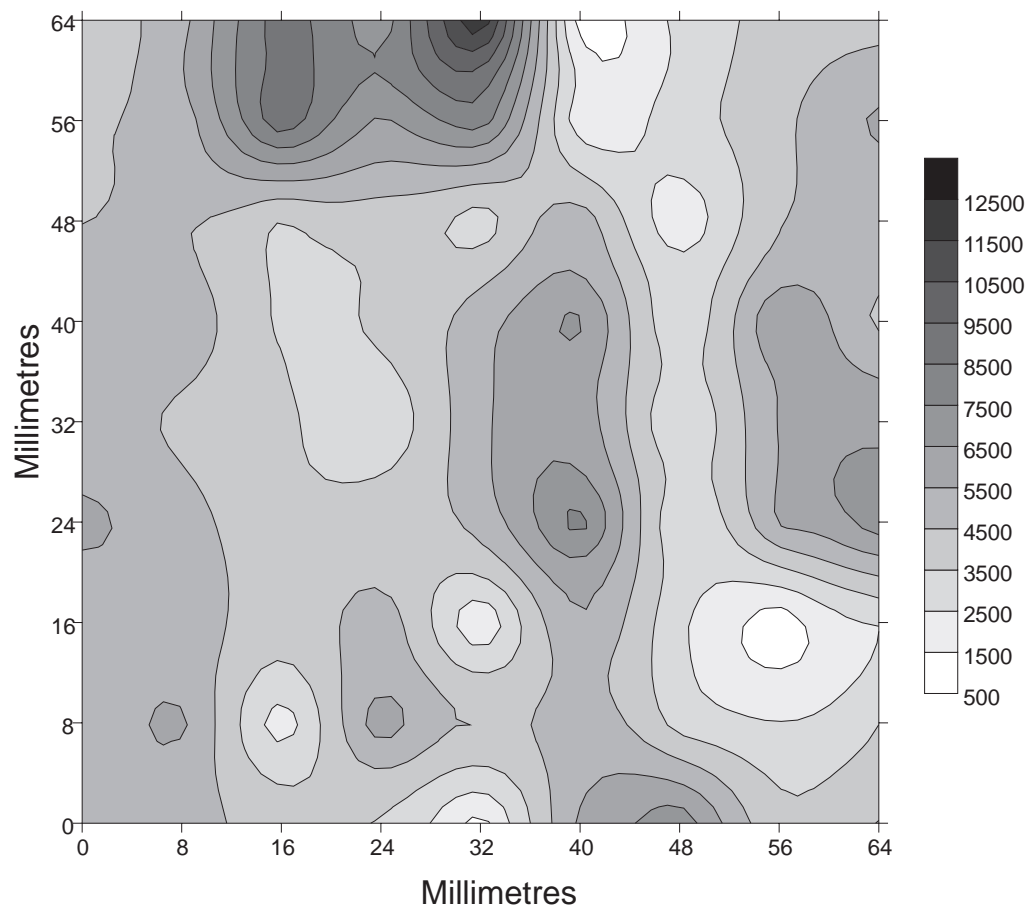

Fig. 4. Two-dimensional $(9 \times 9)$ bacterial distribution patterns at Port River estuary site. Contour graph represents an area of approximately $4000 \mathrm{~mm}^{2}$. Contour scale shows bacteria $\mu l^{-1}$; contour levels set at 1000 bacteria $\mu l^{-1}$ for clarity rates of $0.001 \mathrm{~mW} \mathrm{~kg}^{-1}$ as high levels of turbulence in the open ocean. The energy dissipation rates we used were clearly much higher than this level, but are of the same order of magnitude expected in areas exposed to wave action and within energetic tidal channels (Sanford 1997), and similar to levels established in other laboratory experiments investigating the effect of turbulence on marine plankton (0.2 to $3.8 \mathrm{~mW} \mathrm{~kg}^{-1}$ ) (Howarth et al. 1993).

The mean CV across sample sets taken from the stirred buckets was $18 \%$, and was found to be significantly $(\mathrm{p}<0.05)$ higher than the unstirred samples. A graphical comparison of levels of bacterial heterogeneity in stirred and unstirred samples can be seen in Fig. 5.

Similar findings were obtained with the $5 \times 5$, 2-dimensional sampling device. However, in this instance a sample was also initially taken from the experimental bucket immediately after collection from Pt. Noarlunga. The CV for this 'fresh' sample was $75 \%$ (Fig. 6A). After $24 \mathrm{~h}$ a still sample was taken as above, the CV for this sample was only $5.5 \%$ (Fig. 6B). Additionally, the mean bacterial abundance dropped from $2 \times 10^{3}$ bacteria $\mu l^{-1}$ in the fresh sample to $7 \times 10^{2}$ bacteria $\mu^{-1}$ in the $24 \mathrm{~h}$ settled sample, perhaps indicating the settling out of particles. After stirring the settled sample, the level of heterogeneity increased to a CV of $12.3 \%$, but the mean bacterial abundance did not change from that of the settled sample (Fig. 6C).

\section{Distributions of different particle types in turbulence}

Rod-shaped bacteria and fluorescent $1 \mu \mathrm{m}$ beads could be clearly differentiated using fluorescent microscopy. Mean concentrations were $6.4 \times 10^{6} \mathrm{ml}^{-1}$ for rodshaped bacteria, and $8.9 \times 10^{5} \mathrm{ml}^{-1}$ for fluorescent beads. Following mixing, the CV for rod-shaped bacteria was $33 \%$, and $47 \%$ for fluorescent beads. A clear similarity in distributional patterns of the bacteria and fluorescent spheres across the sample area can be observed in Fig. 7, with 2 regions of minimum and 1 area of maximum abundance appearing to correspond for the 2 particle types. 


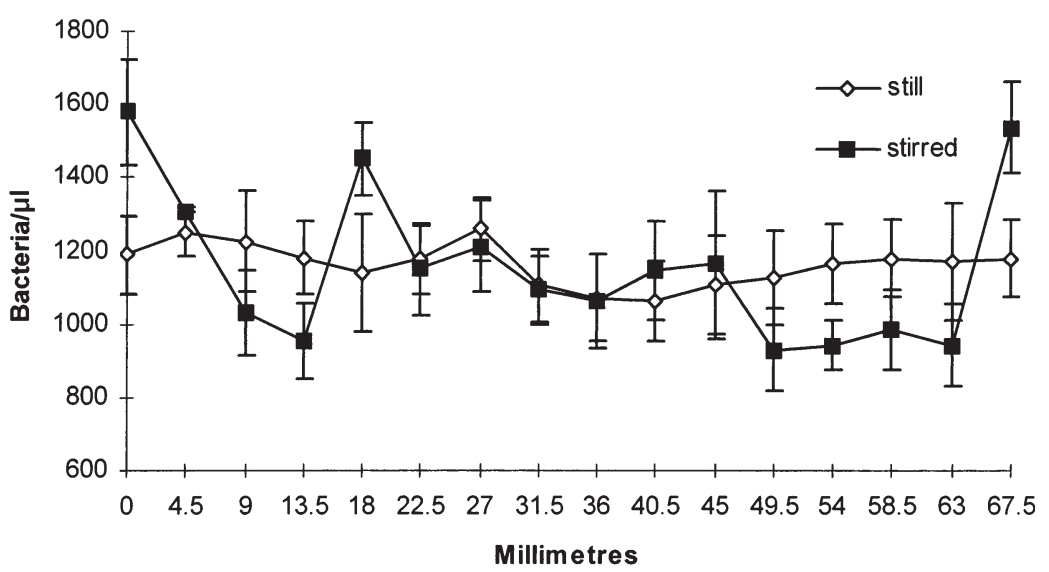

Fig. 5. Comparison of linear bacterial distributions under still and stirred conditions in a bucket of seawater collected from the Port Noarlunga site. Coefficient of variations (heterogeneity measure): still $=5.0 \%$, stirred $=$ $19 \%$. Error bars represent $95 \%$ confidence limits for AODC techniques

happened to sample rare large particles, was not observed, suggesting other mechanisms must be responsible for establishing the obvious structure in bacterial abundance we observed.

All in situ sampling procedures distort the natural bacterial distribution field to some degree. Nevertheless, we are confident that the variations in abundance that we observed were part of the natural bacterial distributions occurring within the ocean, because we observed similar structure and levels of heterogeneity using different sampling devices. The 1- and 2-dimensional sampling devices used have very different structural configurations and we believe each would influence smallscale water flow patterns in very different ways. The flat surface of the 2-dimensional sampling device may damp local

\section{DISCUSSION}

We have shown marine bacteria to be distributed heterogeneously at the millimetre scale. Previously, bacterioplankton abundance has been shown to change by up to 3.5 times over a distance of $10 \mathrm{~cm}$ (Mitchell \& Fuhrman 1989). We observed total changes in bacterial abundance of up to 16 -fold across a gradient of $32 \mathrm{~mm}$ (Fig. 6A). The mechanisms stimulating this heterogeneity are at this stage unclear, but some possibilities are discussed below, as are the implications of the findings of this study.

\section{Structure in bacterial distributions}

Mitchell \& Fuhrman (1989) discussed the occurrence of single point abundance peaks in sample distributions of bacterioplankton, and suggest that they may occur following the collection and disintegration of organic particles during passage through sampling syringes. They suggest that the collection and dispersal of a particle such as a marine snow particle containing many bacteria $\left(2 \times 10^{8}\right.$ particle $^{-1}$, Alldredge et al. 1986) would greatly increase the total concentration of bacteria within a sample.

Processes such as these, however, cannot explain the clear structures in bacterial abundance, sometimes stretching over distances of up to $3 \mathrm{~cm}$ and across several sample syringes, observed in 2-dimensional sample sets (Figs. $3 \& 4$ ), or the multiple point abundance peaks and gradients observed in linear samples (Fig. 2B). Additionally, during counting of bacterial cells under epifluorescent microscopy, clumping of large numbers of bacteria on filters, indicating that we turbulence, and the 1-dimensional array of pipette tips may alter and/or increase small-scale turbulent flow, as water flows around each pipette tip. With each of the devices the same clear gradients and structure in bacterial abundance were observed across comparable distances, suggesting that the devices were not responsible for the production of the patterns in bacterial abundance, and that natural biological or physical processes caused the distributions and structure that we observed.

\section{Turbulence}

According to Mackas et al. (1985) purely biological forcing mechanisms do not appear to be as important for determining levels of plankton patchiness as physicalbiological interactions. Turbulence has been shown to effect levels of bacterial production in both laboratory and field studies (Troussellier et al. 1993, Moeseneder \& Herndl 1995), and it has been suggested that physical processes must be taken into account to explain spatial and temporal patterns of bacterial ecology within marine environments (Troussellier et al. 1993). However, to our knowledge the effects of turbulence on the spatially coherent millimetre-scale distributions of marine bacteria have not previously been studied.

Previous laboratory studies seeking bacterial patchiness have collected natural seawater samples, transported them to the laboratory and left seawater to sit undisturbed over the course of hours (Müller-Niklas et al. 1996). Laboratory experiments conducted in this study found that samples taken from still seawater left undisturbed in a bucket for $24 \mathrm{~h}$ exhibited very homogenous distributions of bacteria, with a mean $\mathrm{CV}$ of 

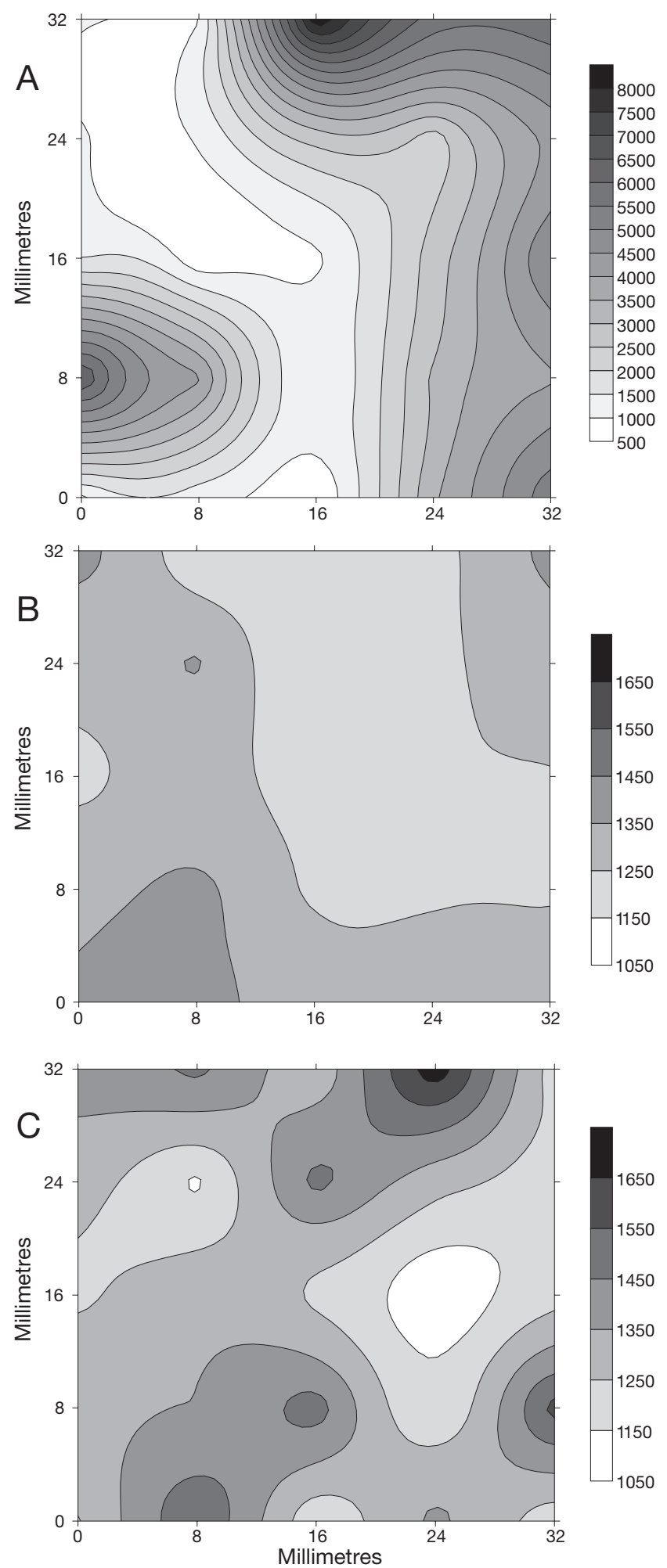

Fig. 6. Two-dimensional representations of bacterial distribution patterns in a bucket of seawater under different conditions. (A) Sample collected after bucket allowed to settle for only $10 \mathrm{~min}(\mathrm{CV}=75 \%)$. (B) Water settled for $24 \mathrm{~h}(\mathrm{CV}=$ $5.5 \%)$. (C) Water stirred $(\mathrm{CV}=12 \%)$. Contour scales represent bacteria $\mu^{-1}$; contour levels set at $95 \%$ confidence limits
$4.5 \%$ observed. Stirring restored patchiness (mean $\mathrm{CV}=18 \%)(\mathrm{p}<0.05)$, suggesting that turbulent mixing plays a role in the establishment of heterogenous distributions of marine bacteria.

Further laboratory experiments comparing the distributions of rod-shaped bacteria and $1 \mu \mathrm{m}$ spherical fluorescent beads in a turbulent water sample found very similar gradients in abundance for the 2 particle types (Fig. 7). Regions of maximum and minimum abundance for the 2 particle types appeared to correspond, perhaps suggesting the physical forcing of particles into certain regions of flow.

A number of theoretical papers have investigated the phenomena of preferential concentration of particles within turbulent flow. Numerical studies have revealed the presence of organised structures in turbulent flows (Vincent \& Meneguzzi 1991), and it has been shown that heavy particles become concentrated into regions of low vorticity or high strain rate (Squires \& Eaton 1991, Wang \& Maxey 1993). Squires \& Yamazaki (1995) extended these findings to suggest that $1 \mathrm{~mm}$ marine particles exposed to isotropic turbulence demonstrate preferential concentration, with peak densities of particles reaching up to 10 to 60 times background levels. However, in an addendum to their paper, Squires \& Yamazaki (1996) conceded that the effect of preferential concentration of marine particles is probably less significant than they had predicted, and Jiménez (1997) added that the preferential concentration of planktonic particles is unlikely in most instances.

However, most of these theoretical studies investigate the properties of newtonian fluids. It is likely that in many instances the ocean is far from a newtonian fluid (Jenkinson 1986). It has been suggested that at the microscale, seawater is an organic matter continuum of tangled polymers and embedded particles (Azam 1998), including transparent exoploymeric particles (TEP) (Alldredge et al. 1993), proteinaceous coomassie stained particles (CSP) (Long \& Azam 1996), and organic sub-micrometer particles (Koike et al. 1990). The potentially gel-like nature of this organic matter continuum (Azam 1998, Chin et al. 1998), and the bulk effects of phytoplankton exuded polysaccharides, may act to increase water viscosity and influence turbulent drag by elastic effects (Jenkinson 1986, Jenkinson \& Biddanda 1995). Lack of rheometrical data taking into account the non-newtonian properties of seawater could impair the accurate modelling of smallscale oceanographic processes (Jenkinson 1986). The rheological properties of the organic matter continuum are likely to effect the influence of small-scale turbulence upon the plankton, and consequently the organic matter continuum should be considered both in terms of biological and physical importance for the microplankton. 
Furthermore, polymer-particle interactions within the organic matter continuum may play an important role in the aggregation of microbes, via processes of polymer bridging (Harris \& Mitchell 1973, Calleja 1984). Additionally, polymers exposed to shear flow have been shown to align and stretch in directions parallel to flow (LeDuc et al. 1999). Hence, turbulent shear in the ocean could influence the dynamics of the polymer gel field, and in turn affect levels of small-scale patchiness of marine bacteria in the sea. However, before an understanding of these processes can be obtained, focussed research into the relationship between marine microorganisms and the polymer matrix in the ocean, and a greater understanding of polymer dynamics within turbulent flow is required.
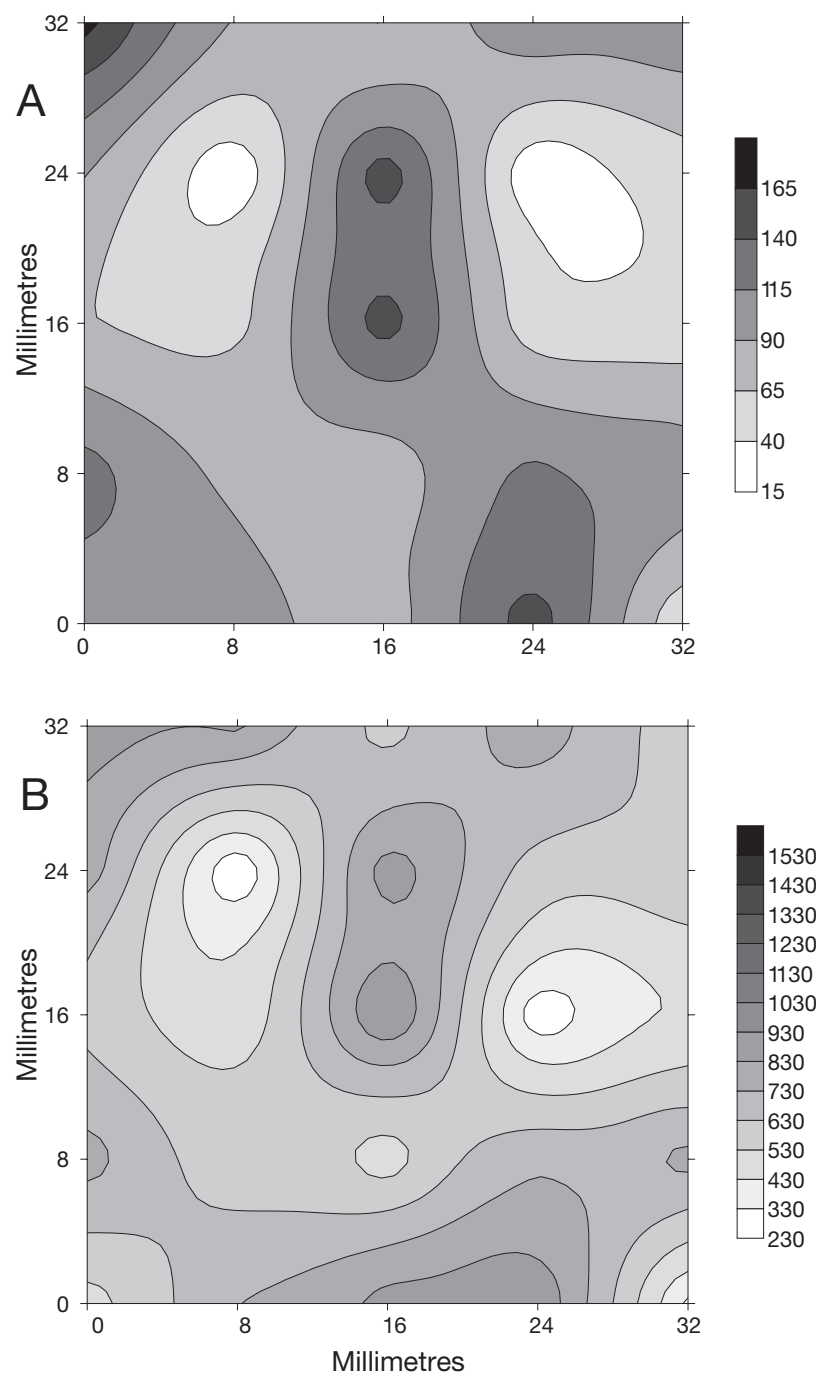

Fig. 7. Two-dimensional representations of (A) $1 \mu \mathrm{m}$ diameter spherical beads and (B) rod-shaped bacteria distribution patterns in a bucket of filtered $(0.2 \mu \mathrm{m})$ seawater. Contour scales represent particles $\mu l^{-1}$; contour levels set at $95 \%$ confidence limits for AODC techniques

\section{Particle aggregation in turbulence}

While our field and laboratory data provide some evidence for the preferential concentration of particles within turbulent flow, another component of the laboratory study suggests that resuspension from mixing could be important for determining bacterial distributions.

When a sample was taken from a bucket of seawater immediately after collection from a turbulent study location, high levels of heterogeneity were observed, with a CV of $75 \%$ calculated (Fig. 6A). A water sample taken from the same bucket $24 \mathrm{~h}$ later showed a homogenous distribution of bacteria, with a CV of only $5.5 \%$ (Fig. 6B). Importantly, the total bacterial concentration of the still water sample set was found to be 4 times lower than in the initial sample. This could suggest that bacteria observed in the initial sample were associated with particles, which after $24 \mathrm{~h}$ settled out of the sampling area $(10 \mathrm{~cm}$ below the water surface). The increase in heterogeneity to a CV of $11.5 \%$ following mixing of the settled sample (Fig. 6C) may have been due to the resuspension of these particles.

For a particle to settle out of the sampling area (depth $10 \mathrm{~cm}$ ) during the $24 \mathrm{~h}$ period that the sample was left undisturbed, it would require a settling velocity of $W_{\mathrm{s}}=1.2 \times 10^{-4} \mathrm{~cm} \mathrm{~s}^{-1}$. According to McCave (1984) particles with a diameter of $5 \mu \mathrm{m}$ would have an associated density contrast $\Delta \rho=4.6 \times 10^{-4}\left(\left[\rho_{\mathrm{s}}-\rho\right]\right.$, where $\rho_{\mathrm{s}}$ is particle density and $\rho$ is fluid density, here taken as $1.05 \mathrm{~g} \mathrm{~cm}^{-3}$ ), and according to Stokes' Law would have $W_{\mathrm{s}}=4.6 \times 10^{-4} \mathrm{~cm} \mathrm{~s}^{-1}$. Larger particles with $1000 \mu \mathrm{m}$ diameter would have $\Delta \rho=3.89 \times 10^{-3} \mathrm{~g} \mathrm{~cm}^{-3}$, and $W_{\mathrm{s}}=0.1410 \mathrm{~cm} \mathrm{~s}^{-1}$ (McCave 1984). Hence, if we assume that all particles between the size range of 5 to $<1000 \mu \mathrm{m}$ settled out of the sampling area, particles including marine snow $(>0.5 \mathrm{~mm})$, TEP (3 to $100 \mu \mathrm{m})$ (Alldredge et al. 1993), and CSP (2 to $150 \mu \mathrm{m}$ ) (Long \& Azam 1996) would have no longer been in the sample area at time of sampling. Marine bacteria have been shown to be associated with each of these particle types in nature (Alldredge et al. 1986, 1993, Long \& Azam 1996). During the time that these particles were absent from the sampling region a comparatively homogenous distribution of bacteria was observed, suggesting that the presence of marine particles may be important for maintaining heterogenous distributions of bacteria at the millimetre scale within the ocean.

Oceanic turbulence probably maintains this particle associated heterogeneity in bacterial abundance by resuspending particles within the water column. It has also been shown that turbulence can act to increase aggregate formation by increased collision rates and coagulation of particles (McCave 1984, Kiørboe 1997, 
Ruiz 1997), as well as to break apart organic aggregates (Ruiz 1997, Ruiz \& Izquierdo 1997). TEP, shown to be an important factor in the coagulation of larger particles (Logan et al. 1995), has also been shown to be influenced by turbulence levels (Schuster \& Herndl 1995). Hence, turbulence plays an important role in influencing size ranges and distributions of marine particles, and thus, in terms of bacteria-particle interactions, probably has a large effect on bacterial distribution patterns.

\section{Implications of millimetre-scale bacterial heterogeneity}

Spatial heterogeneity of organisms is critically important in regulating community compositions and population dynamics (Powell et al. 1975, Powell \& Okubo 1994). Small-scale heterogeneity in bacterial abundance is likely to be an important factor influencing density-dependent predation on bacteria, and hence carbon flow through the microbial loop (Azam \& Ammerman 1984). Fenchel (1980) suggested that given the average bacterial abundance in the open ocean, ciliates could not play a major role as bacterivores, as bacterial densities are too low. However, heterogenous, or patchy, distributions of organisms alter predator-prey interactions. Predators, such as ciliates and heterotrophic flagellates, are more likely to survive where food rations are patchy, because grazing efficiency should be enhanced in high density bacterial patches, rather than in sparse uniformly distributed populations (Owen 1989, Duarte \& Vaqué 1992). Azam \& Ammerman (1984) suggest that situations where bacterial abundance around algal cells may reach $7 \times 10^{7} \mathrm{ml}^{-1}$, compared to concentrations of $10^{6} \mathrm{ml}^{-1}$ in the bulk phase, may be an important factor in the sustenance of protozoan populations, and the subsequent maintenance of the flow of carbon through the microbial loop.

The heterogeneity measured in our study was, however, at the wrong scale to be directly created by the nanoscale processes discussed by Azam \& Ammerman (1984). We suggest that these nanoscale processes including microzone formation (Azam \& Ammerman 1984, Mitchell et al. 1985) and nutrient patches (Blackburn et al. 1998) probably occur merely as periodic maxima within a continuously heterogenous distribution of bacteria within the marine environment. Whether the heterogeneity we observed across distances of a few millimetres has as great an ecological significance for bacterivores is not clear, although a 16-fold change in bacterial abundance over a distance of $3.2 \mathrm{~cm}$ could form a strong, if transient, signal for micro- and mesozooplankton indicating a concentrated resource patch.
Azam (1998) suggested that biogeochemical variability should be considered as a consequence of microenvironmental events. Bacterial heterogeneity would lead to the localisation of bacterial carbon uptake, which according to Cho \& Azam (1988) could strongly influence patterns of marine biogeochemical cycling.

The scale at which such processes are best studied and understood, at least initially, are those at which greatest levels of heterogeneity occur. Comparison of the results presented here with those of Duarte \& Vaqué (1992), Müller-Niklas et al. (1996) and Mitchell \& Fuhrman (1989) suggests that millimetre-scale variations may at this stage be most revealing for the study of small-scale bacterial processes occurring in the ocean.

Acknowledgements. We are grateful to Dr Adele Pile, Emily Day, and the staff of the Clinical Immunology Department of the Flinders Medical Centre, South Australia, for providing instruction and support in flow cytometry. Thanks to Dick Edyvean for constructing the $5 \times 5$ and $9 \times 9,2$-dimensional sampling devices. We furthermore thank the 4 anonymous reviewers for their constructive comments on the manuscript. Funding for this research was provided by the Australian Research Council and the Flinders University School of Biological Sciences.

\section{LITERATURE CITED}

Alldredge AL, Cohen Y (1987) Can microscale chemical patches persist in the sea? Microelectrode study of marine snow, fecal pellets. Science 235:689-691

Alldredge AL, Cole JJ, Caron DA (1986) Production of heterotrophic bacteria inhabiting macroscopic organic aggregates (marine snow) from surface waters. Limnol Oceanogr 31(1):68-78

Alldredge AL, Passow U, Logan BE (1993) The abundance and significance of a class of large, transparent organic particles in the ocean. Deep-Sea Res 40:1131-1140

Azam F (1998) Microbial control of oceanic carbon flux: the plot thickens. Science 280:694-696

Azam F, Ammerman JW (1984) Cycling of organic matter by bacterioplankton in pelagic marine ecosystems: microenvironmental considerations. In: Fasham MJR (ed) Flows of energy and materials in marine ecosystems. Plenum Press, New York, p 345-360

Azam F, Fenchel T, Field JG, Gray JS, Meyer-Reil LA, Thingstad F (1983) The ecological role of water-column microbes in the sea. Mar Ecol Prog Ser 10:257-263

Blackburn N, Azam F, Hagström ^̊ (1997) Spatially explicit simulations of a microbial food web. Limnol Oceanogr 42(4):613-622

Blackburn N, Fenchel T, Mitchell JG (1998) Microscale nutrient patches in plankton habitats shown by chemotactic bacteria. Science 282:2254-2256

Bowen JD, Stolzenbach KD, Chisholm SW (1993) Simulating bacterial clustering around phytoplankton cells in a turbulent ocean. Limnol Oceanogr 38:36-51

Calleja GB (1984) Microbial aggregation. CRC Press, Boca Raton, FL 
Chin WC, Orellana MV, Verdugo P (1998) Spontaneous assembly of marine disolved organic matter into polymer gels. Nature 391:568-572

Cho BC, Azam F (1988) Major role of bacteria in biogeochemical fluxes in the oceans interior. Nature 332:441-443

Duarte CM, Vaqué D (1992) Scale dependence of bacterioplankton patchiness. Mar Ecol Prog Ser 84:95-100

Fenchel T (1980) Suspension feeding in ciliated protozoa: feeding rates and their ecological significance. Microb Ecol 6:1-12

Harris RH, Mitchell R (1973) The role of polymers in microbial aggregation. Annu Rev Microbiol 27:27-50

Haury LR, Yamazaki H, Itsweire EC (1990) Effects of turbulent shear flow on zooplankton distribution. Deep-Sea Res 37:447-461

Hobbie JE, Daley RJ, Jasper S (1977) Use of nucleopore filters for counting bacteria by epifluorescence microscopy. Appl Environ Microbiol 33:1225-1228

Howarth RW, Butler T, Lunde K, Swaney D, Chu CR (1993) Turbulence and planktonic nitrogen fixation: a mesocosm experiment. Limnol Oceanogr 38:1696-1711

Jenkinson IR (1986) Oceanographic implications of non-Newtonian properties found in phytoplankton cultures. Nature 323:435-437

Jenkinson IR, Biddanda BA (1995) Bulk-phase viscoelastic properties of seawater: relationship with plankton components. J Plankton Res 17(12):2251-2274

Jiménez J (1997) Oceanic turbulence at millimeter scales. Sci Mar 61(Suppl 1):47-56

Kiørboe T (1993) Turbulence, phytoplankton cell size and the structure of pelagic food webs. Adv Mar Biol 29:1-72

Kiørboe T (1997) Small-scale turbulence, marine snow formation, and planktivorous feeding. Sci Mar 61(Suppl 1): 141-158

Koike I, Shigemitsu H, Kazuki T, Kogure K (1990) Role of submicrometer particles in the ocean. Nature 345:242-244

Krembs C, Juhl AR, Strickler JR (1998a) The spatial information preservation method: sampling the nanoscale spatial distribution of microorganisms. Limnol Oceanogr 43(2): 298-306

Krembs C, Juhl AR, Long RA, Azam F (1998b) Nanoscale patchiness of bacteria in lake water studied with the spatial information preservation method. Limnol Oceanogr 43(2):307-314

LeDuc P, Haber C, Bao G, Wirtz D (1999) Dynamics of individual flexible polymers in a shear flow. Nature 399: 564-566

Lehman JT, Scavia D (1982) Microscale patchiness of nutrients in plankton communities. Science 216:729-730

Logan BE, Passow U, Alldredge AL, Grossart HP, Simon M (1995) Rapid formation and sedimentation of large aggregates is predictable from coagulation rates (half-lives) of transparent exopolymer particles (TEP). Deep-Sea Res II 42(1):203-214

Long RA, Azam F (1996) Abundant protein-containing particles in the sea. Aquat Microb Ecol 10:213-221

Mackas DL, Denman KL, Abbott MR (1985) Plankton patchiness: biology in the physical vernacular. Bull Mar Sci 37(2): 652-674

Mann KH, Lazier JRN (1991) Dynamics of marine ecosystems: biological-physical interactions in the oceans. Blackwell Scientific Publications, Cambridge, MA

Marie D, Partensky F, Jacquet S, Vaulot D (1997) Enumera-

Editorial responsibility: Fereidoun Rassoulzadegan,

Villefranche-sur-Mer, France tion and cell cycle analysis of natural populations of marine picoplankton by flow cytometry using a novel nucleic acid dye. Appl Environ Microbiol 63:186-193

McCave IN (1984) Size spectra and aggregation of suspended particles in the deep ocean. Deep-Sea Res 31:1721-1733

Mitchell JG, Fuhrman JA (1989) Centimeter scale vertical heterogeneity in bacteria and chlorophyll a. Mar Ecol Prog Ser 54:141-148

Mitchell JG, Okubo A, Fuhrman JA (1985) Microzones surrounding phytoplankton form the basis for a stratified marine microbial ecosystem. Nature 316:58-59

Moeseneder MM, Herndl GJ (1995) Influence of turbulence on bacterial production in the sea. Limnol Oceanogr 40(8): 1466-1473

Müller-Niklas G, Agis M, Herndl GJ (1996) Microscale distribution of bacterioplankton in relation to phytoplankton: results from 100-nl samples. Limnol Oceanogr 41(7): $1577-1582$

Owen RW (1989) Microscale and finescale variations of small plankton in coastal and pelagic environments. J Mar Res 47:197-240

Pomeroy LR (1974) The oceans foodweb, a changing paradigm. Bioscience 24:499-504

Powell TM, Okubo A (1994) Turbulence, diffusion and patchiness in the sea. Phil Trans R Soc Lond B 343:11-18

Powell TM, Richerson PJ, Dillon TM, Agee BA, Dozier BJ, Godden DA, Myrup LO (1975) Spatial scales of current speed and phytoplankton biomass fluctuations in Lake Tahoe. Science 189:1088-1089

Ruiz J (1997) What generates daily cycles of marine snow? Deep-Sea Res I 44(7):1105-1126

Ruiz J, Izquierdo A (1997) A simple model for the break-up of marine aggregates by turbulent shear. Oceanol Acta 20(4): $597-605$

Sanford LP (1997) Turbulent mixing in experimental studies. Mar Ecol Prog Ser 161:265-293

Schuster S, Herndl GJ (1995) Formation and significance of transparent exopolymeric particles in the northern Adriatic Sea. Mar Ecol Prog Ser 124:227-236

Shanks AL, Trent JD (1979) Marine snow: microscale nutrient patches. Limnol Oceanogr 24:850-854

Squires KD, Eaton JK (1991) Preferential concentration of particles by turbulence. Phys Fluids 3:1169

Squires KD, Yamazaki H (1995) Preferential concentration of marine particles in isotropic turbulence. Deep-Sea Res 42: 1989-2004

Squires KD, Yamazaki H (1996) Addendum to the paper 'Preferential concentration of marine particles in isotropic turbulence'. Deep-Sea Res I 43(11-12):1865-1866

Troussellier M, Cahet G, Lebaron P, Baleux B (1993) Distribution and dynamics of bacterial production in relation to wind perturbations in a Mediterranean lagoon. Limnol Oceanogr 38:193-201

Vaulot D (1989) CytoPC: processing software for flow cytometric data. Signal Noise 2:8

Vincent A, Meneguzzi M (1991) The spatial structure and statistical properties of homogenous isotropic turbulence. J Fluid Mech 225:1

Wang LP, Maxey MR (1993) Settling velocity and concentration distribution of heavy particles in homogenous isotropic turbulence. J Fluid Mech 256:27-68

Yamazaki H (1993) Lagrangian study of planktonic organisms: perspectives. Bull Mar Sci 53:265-27

Submitted: January 28, 2000; Accepted: May 26, 2000

Proofs received from author(s): July 27, 2000 